\title{
УГЛЕВОДОРОДНЫЕ РЕСУРСЫ АРКТИЧЕСКОГО МАКРОРЕГИОНА
}

\section{Серова Н.А.}

Институт экономических проблем им. Г.П. Лузина КНЦ РАН, Anamumb, serova@iep.kolasc.net.ru

На сегодняшний день углеводородное сырье является основным источником удовлетворения потребности мирового сообщества в энергоресурсах, и, несмотря на замедление глобального энергопотребления, которое наметилось на мировых энергетических рынках, в перспективе зависимость человечества от углеводородов будет не только сохраняться, но и усиливаться.

Одним из самых богатых регионов в мире по обеспеченности углеводородами является Арктический макрорегион. Однако из-за его слабой изученности, особенно шельфа Северного Ледовитого океана, полной и достоверной оценки запасов арктических углеводородов на сегодняшний день не существует. Так, согласно оценкам Геологической службы CША (USGS) в Арктике содержится около 22-25 \% мировых запасов нефти и газа [8]. Потенциальные запасы нефти в этом регионе оцениваются экспертами USGS в 95,7 млрд. баррелей нефти, 49.45 трлн. м³ природного газа, 44.7 млрд. баррелей газоконденсата [9, с. 151-161].

По данным экспертов из американского Национального нефтяного Совета (National Petroleum Council) на Арктический регион приходится до 25 \% всех неразведанных ресурсов углеводородов. Потенциальные углеводородные ресурсы оцениваются в 95.7 млрд. баррелей нефти, 49.45 трлн. м природного газа и 44.7 млрд. бар. газового конденсата, а в целом общий потенциал углеводородных ресурсов Арктики составляет около 105.7 млрд. баррелей нефти, 64.5 трлн. м³ природного газа и 47 млрд. баррелей газового конденсата (табл.) [7].

Общий потенциал углеводородных ресурсов Арктики, 2015 г.

\begin{tabular}{|c|c|c|c|c|c|c|}
\hline & \multicolumn{2}{|c|}{$\begin{array}{c}\text { Нефть, } \\
\text { млрд. бар. }\end{array}$} & \multicolumn{2}{|c|}{ Газ, трлн.м ${ }^{3}$} & \multicolumn{2}{|c|}{$\begin{array}{l}\text { Газ. кон., } \\
\text { млрд.бар. }\end{array}$} \\
\hline & Суша & Шельф & Суша & Шельф & Суша & Шельф \\
\hline \multicolumn{7}{|c|}{ НЕРАЗВЕДАННЫЕ РЕСУРСЫ } \\
\hline Арктическая зона РФ & 12.6 & 17.9 & 4.80 & 28.25 & 4.4 & 23.1 \\
\hline Другие приарктические страны & 12.2 & 53.0 & 3.19 & 13.21 & 2.7 & 14.5 \\
\hline США & 9.9 & 21.9 & 2.64 & 4.01 & 2.4 & 3.4 \\
\hline Норвегия & 0.1 & 4.5 & 0.03 & 3.24 & 0.0 & 1.0 \\
\hline Канада & 1.4 & 11.3 & 0.34 & 2.21 & 0.2 & 1.3 \\
\hline Гренландия & 0.8 & 15.3 & 0.18 & 3.75 & 0.1 & 8.8 \\
\hline \multicolumn{7}{|c|}{ РАЗВЕДАННЫЕ РЕСУРСЫ } \\
\hline Арктическая зона РФ & 4.6 & 0.5 & 5.31 & 5.12 & 1.0 & 0.5 \\
\hline Другие приарктические страны & 1.8 & 3.1 & 3.24 & 1.36 & 0.0 & 0.8 \\
\hline США & 1.4 & 0.7 & 2.88 & 0.81 & 0.0 & 0.7 \\
\hline Норвегия & 0.0 & 0.9 & 0.0 & 0.23 & 0.0 & 0.1 \\
\hline Канада & 0.4 & 1.5 & 0.36 & 0.32 & 0.0 & 0.0 \\
\hline Гренландия & 0.0 & 0.0 & 0.0 & 0.0 & 0.0 & 0.0 \\
\hline
\end{tabular}

Источник: составлено автором по данным National Petroleum Council.

По оценке экспертов USGS почти 75 \% неразведанных запасов углеводородов находятся на шельфе Северного Ледовитого океана. При этом около 30 \% запасов нефти находится на Аляске, а запасы природного газа сосредоточены преимущественно на российском шельфе (в ЗападноСибирском бассейне и в восточной части Баренцева моря).

Отечественная наука также имеет огромный опыт изучения геологии и оценки ресурсов углеводородов Арктики. Формирование современных представлений о геологии и нефтегазоносности арктических бассейнов связано с именами Н.А. Богданова, А.Э. Конторовича, Ю.Е. Погребицкого, В.Е. Хаина и др. Наиболее значительный вклад в формирование современных представлений 
о геологии и нефтегазоносности арктических бассейнов внесла научная школа выдающегося исследователя геологии Арктики и Северного Ледовитого океана академика И.С. Грамберга. Еще в начале 2000-х гг., выполняя сравнительный анализ геологии и нефтегазоносности океанов Земли, И.С. Грамберг пришел к выводу о четкой зависимости между масштабом нефтегазоносности континентальных окраин океанов и уровнем их геологической зрелости [2, с. 3-19]. По его мнению, океаны, находящиеся на ранней стадии развития, к которым относится Северный Ледовитый океан, наиболее богаты запасами углеводородов. Это заключение подтверждается и исследованием Института нефтегазовой геологии и геофизики СО РАН, согласно которому начальные геологические ресурсы углеводородов в Северном Ледовитом океане в нефтяном эквиваленте составляют от 90 до 252 млрд. тонн, в Атлантическом и Индийском океанах от 35 до 70 млрд. тонн, а в Тихом, самом древнем океане всего 10-25 млрд. тонн [4, с.7-17].

В настоящее время в Арктическом макрорегионе добывается десятая часть общемировых объёмов нефти и четверть природного газа. При этом на континентальных окраинах арктических морей, реализуются лишь единичные проекты - в США (на Аляске), Норвегии (в Баренцевом море) и России (в Печорском море). Так, на арктическом континентальном шельфе США добыча ведется только в море Бофорта, а все морские нефтяные проекты осуществляются на удалении не более 10 миль от побережья, причем месторождения разрабатываются либо с берега путем бурения горизонтальных скважин, либо с искусственных островов. К самым большим морским месторождениям относятся нефтяное Endicott (запасы оцениваются в 570 млн. баррелей нефти) и Point McIntyre (590 млн. баррелей нефти и 17 млрд. м³ газа) [1, с. 96].

На сухопутной территории американского сектора Арктики добыча ведется на Северном склоне Аляски, потенциал неразведанных углеводородных запасов которого составляет 15.908 млрд. баррелей нефти и газоконденсата и около 2.86 трлн. м³ природного газа [7]. Крупнейшим месторождением Северного склона является газонефтяное месторождение Prudhoe Bay, запасы которого оцениваются в 2.449 млрд. баррелей нефти и 707.8 млн. м³ природного газа. Кроме того, огромную территорию Северного склона занимают Национальный нефтяной резерв (запасы по разным оценкам составляют от 600 млн. до 1.6 млрд. баррелей нефти и от 1.458 трлн. м³ до 1.773 трлн. м природного газа) и Арктический национальный заповедник (запасы составляют от 9.0 до 10.4 млрд. баррелей нефти и газоконденсата и от 109.7 млрд. м³ до 208 млрд. м $^{3}$ природного газа), где добыча на сегодняшний день не ведется по соображениям стратегического и природоохранного характера [10, с. 73-90].

Все углеводородные месторождения Норвегии сосредоточены на континентальном шельфе в акваториях Северного, Норвежского и Баренцева морей. На арктическом континентальном шельфе в акватории Баренцева моря в промышленной эксплуатации находятся только газовое Snohvit (неразведанные технически извлекаемые запасы газа оцениваются в 193 млрд. м природного газа и 113 млн. м ${ }^{3}$ конденсата) и нефтяное Goliat (неразведанные технически извлекаемые запасы оцениваются в 180 млн. баррелей нефти и 8 млрд. м $^{3}$ природного газа). Помимо них, в Баренцевом море открыты еще несколько месторождений, обладающих коммерческими запасами нефти, в частности Johan Castberg, Gohta, Alta и Wisting Central. Однако в связи с падением мировых цен на нефть инвестиционные решения по их разработке пока не приняты.

Нефтегазовыми запасами на континентальном шельфе Арктики обладают также Гренландия и Канада. В настоящее время добыча здесь не ведется, тем не менее, в этих странах накоплен значительный опыт геологоразведочных работ, которые проводились еще в 1970-1980-е гг. прошлого века. Однако, несмотря на большой объем поисково-разведочных работ, крупные месторождения, как в канадском секторе моря Бофорта, так и на гренландском арктическом шельфе (море Баффина), обнаружены не были.

Наибольшим ресурсным потенциалом в Арктике обладает Россия. Основные запасы углеводородов российского сектора Арктики находятся на западно-арктическом шельфе в акваториях Баренцева и Карского морей, где на сегодняшний день открыто более 20 крупных месторождений (газоконденсатные - Ленинградское, Русановское и крупнейшее в мире Штокмановское (прогнозные ресурсы - 3.9 трлн. м газа и 56.1 млн. тонн газового конденсата), газовые - Мурманское и Северо-Кильдинское, нефтяные - Долгинское и Приразломное, нефтегазоконденсатное - Юрхаров- 
ское и др.). По мнению акад. А.Э. Конторовича, научного руководителя Института нефтегазовой геологии и геофизики СО РАН, запасы углеводородов российского арктического бассейна сопоставимы с углеводородными провинциями Ближнего Востока и Западной Сибири и составляют более 280 млрд. тонн (нефти, природного газа и газового конденсата) [3, с. 46-65].

Добыча нефти на континентальном шельфе российской Арктики добыча ведется только на Приразломном месторождении в Печорском море, эксплуатация которого началась в конце 2013 г. (извлекаемые запасы месторождения превышают 70 млн. тонн нефти), а добыча газа ведется только в материковой части Арктики [5].

Ведущим арктическим регионом по запасам нефти и природного газа является Ямало-Ненецкий AО, на долю которого приходится около 75 \% разведанных запасов природного газа страны.

Крупнейшими месторождениями округа являются Южно-Русское (запасы нефти составляют 16.15 \% округа), Заполярное, Уренгойское, Медвежье, Ямбургское (занимает третье место в мире по начальным извлекаемым запасам газа), Бованенковское и др. В округе реализуется крупнейший во всей Арктике нефтегазовый проект «Ямал СПГ» (общий объем инвестиций в проект оценивается в трлн. рублей), в рамках которого за счёт внебюджетных источников в 2013-2015 гг. построены международный аэропорт и морской порт Сабетта (инвестиции в порт составили около 108 млрд.руб., в том числе более 70 млрд.руб. за счет федерального бюджета), предназначенный для перевалки углеводородного сырья Южно-Тамбейского газоконденсатного месторождения и поставок сжиженного природного газа в страны Западной Европы и Америки, а также ведется строительство завода по сжижению природного газа [6, с. 13-20].

В целом, не вызывает сомнений, что значительное увеличение поисковых геологоразведочных исследований и подготовка на российском арктическом шельфе сырьевых баз для формирования новых центров добычи углеводородов имеет стратегический характер и будет играть очень важную роль в обеспечении национальной безопасности страны.

Публикация выполнена в рамках госзадания ФИЦ КНЦ РАН № 0226-2018-0005_ИЭП, а также в рамках гранта РФФИ №16-06-00056А «Оценка воздействий прогнозируемых изменений геологической среды на локальные и глобальные мирохозяйственные процессы».

\section{Литература}

1. Арктический регион: Проблемы международного сотрудничества / Российский совет по международным делам; под общ. ред. И.С. Иванова. М.: Аспект-Пресс. 2013. Т. 2. 384 с.

2. Грамберг И.С. Сравнительная геология и минерагения океанов и их континентальных окраин с позиций стадийного развития океанов // Геотектоника. 2001. № 6. С. 3-19.

3. Конторович А.Э. Нефть и газ Российской Арктики: история освоения в XX веке, ресурсы, стратегия на XX век // Наука из первых рук. 2015. Т. 61. № 1. С. 46-65.

4. Конторович А.Э., Эпов М.И., Бурштейн Л.М., Каминский В.Д., Курчиков А.Р., Малышев Н.А., Прищепа О.М., Сафронов А.Ф., Ступакова А.В., Супруненко О.И. Геология, ресурсы углеводородов шельфов арктических морей России и перспективы их освоения // Геология и геофизика. 2010. Т. 5. № 1. С. 7-17.

5. Регионы Севера и Арктики Российской Федерации: современные тенденции и перспективы развития / Под науч. ред. д.э.н., проф. Т.П. Скуфьиной, к.э.н. Н.А. Серовой. Апатиты: КНЦ РАН. 2017. 166 с.

6. Серова Н.А. Особенности инвестиционной политики регионов Арктической зоны // Север и рынок: формирование экономического порядка. 2016. № 3. С. 13-20.

7. Arctic Potential: Realizing the Promise of U.S. Arctic Oil and Gas Resources / National Petroleum Council, 2015. Part One. URL: www.npcarcticpotentialreport.org (date of access: 06.03.2018).

8. Gautier D.L, Bird K.J., Charpentier R.R., Grantz A., Houseknecht D.W., Klett T.R., Moore T.E., Pitman J.K., Schenk Ch.J., Schuenemeyer J.H., Sorensen K., Tennyson M.E., Valin Z.C., Wandrey C.J. Assessment of Undiscovered Oil and Gas in the Arctic // Science. 2009. V. 324. P. 1175-1179. DOI: 10.1126/science.1169467.

9. Gautier D.L., Bird K.J., Charpentier R.R., Grantz A., Houseknecht D.W., Klett T.R., Moore T.E., Pitman J.K., Schenk Ch.J., Schuenemeyer J.H., Sorensen K., Tennyson M.E., Valin Z.C., Wandrey C.J. Oil and gas resource potential north of the Arctic Circle / Chapter 9: in Arctic Petroleum Geology. Edited by Spencer A.M., Embry A.F., Gautier D.L., Stoupakova A.V., Sørensen K. Geological Society of London. 2011. V. 35. P.151-161. DOI: $10.1144 / \mathrm{M} 35.9$.

10. Waters M.A., Swenson R.F., LePain1 D.L., Clough1 J.G. Fossil fuels and geothermal energy sources for local use in Alaska / Alaska Department of Natural Resources, Division of Geological \& Geophysical Surveys, 2012. Special Report 66. P. 73-90. 